\title{
Laser Scanning Confocal Microscopy Characterization of Conservation Products Distribution in Building Stone Porous Network
}

\author{
Zoghlami, K. ${ }^{1}$ and Gomez Gras, D. ${ }^{2}$ \\ 1 Université 7 Novembre à Carthage, Faculté des Science de Bizerte \\ ¿Universidad Autónoma de Barcelona, Departament de Geologia \\ 1Tunisia \\ 2Spain
}

\section{Introduction}

Stone has been used as a building material for thousands of years. It has long been recognised as a material of great durability and superior artistic quality, the foremost choice for buildings associated with status, power and religion. The pyramids in Giza, Burial Chambers in the UK and The Prehistoric Temples Of Malta were all built from stone over 4000 years ago and are still standing. The use of stone in construction has declined over the last hundred years, but it remains an aristocrat of building materials.

Building stone derives from one of three naturally occurring rock types:

Igneous rocks: Rrocks are buried deep within the Earth, they melt because of the high pressure and temperature; the molten rock (magma) can then flow upward or even be erupted from a volcano onto the Earth's surface. When magma cools slowly, usually at depths of thousands of feet, crystals grow from the molten liquid, and a coarse-grained rock forms. The best example is Granite.

When magma cools rapidly, usually at or near the Earth's surface, the crystals are extremely small, and a fine-grained rock results. The fame example is Basalts. A wide variety of rocks are formed by different cooling rates and different chemical compositions of the original magma. Both varieties correspond to a hard and non-porous rock.

Sedimentary rocks: are formed at the surface of the Earth, either in water or on land. They are layered accumulations of sediments-fragments of rocks, minerals, or animal or plant material. Most sedimentary rocks become cemented together by minerals and chemicals or are held together by electrical attraction; some, however, remain loose and unconsolidated. Consolidate Sedimentary rocks are Soft and fairly porous rock widely used as building materials, the best examples are sandstone and limestone.

Metamorphic rocks: Hard and non-porous rock formed from pre-existing rock that has been transformed by intense heat or pressure within the Earth's crust. The process of metamorphism does not melt the rocks, but instead transforms them into denser, more compact rocks. New minerals are created either by rearrangement of mineral components or by reactions with fluids that enter the rocks. Some kinds of metamorphic such as gneiss and biotite schist are two strongly banded or foliated. Pressure or temperature can even change 
previously metamorphosed rocks into new types. The most metamorphic rocks used in construction are marble and slate.

There are huge variations within each of these rock types, caused by specific mineralogy and geology conditions, and while any stone can be used for building, they each have constraints that make them more or less suitable for different purposes. Granite, sandstone and limestone can all be used for building walls, but slate is only suitable for roofs and floors. Some types of granite can contain mineral salts that cause spalling, where the outer face of stone falls off; slate can contain harmful minerals that break down on exposure to the atmosphere causing stone damage; and sandstone can be too porous and fragile for loadbearing structures. An understanding of how the rock material was formed will reveal how it can be used in a building, what its limitations are, how it will weather over time and how it can be treated for its conservation.

The term rock refers to the bulk volume of the material, including the grains or crystals as well as the contained void space. The volumetric portion of bulk rock that is not occupied by grains, crystals, or natural cementing material is termed porosity. That is to say, porosity is the ratio of void volume to the bulk volume. This void space consists of pore space between grains or crystals, in addition to crack space. There are several types of porosity. In endogenous rocks, porosity is mainly fissural type. However, in sedimentary rocks, the amount of pore space depends on the degree of compaction of the sediment, and on the formation history of the rock. We can found one or more porosity types in the same rock. This may lead to the presence of one or several families of pore and therefore one or more pore networks. This pore networks can be interconnected or not.

As well as many engineering materials pore structure influence the physical and mechanical properties of building stone, including elastic module, compressibility, thermal conductivity, poroelastic parameters, strength, and failure behavior.

The transport properties in particular depend critically on the geometry of pores (Adler, 1992; Dullien, 1992; Sahimi, 1995). In fact, size, shape, connectivity, and the tortuosity of the pore space affect the permeability of the porous medium more strongly than the total void fraction available to transmit that flow (Petford et al., 1999).

Secondly, the study of porosity is determinative in to assess and predict rock weathering phenomenon (Zoghlami et al. 2004). In fact, rock decay depends not only on the rate of porosity which can be determined by various means but also on the porous network characterizations. Critical parameters such as pore connectivity, size distribution and tuortuosity play a major role in governing decay in porous rocks. As an example, consider a quartzarenite with a bulk porosity of $20-25 \%$ which $70 \%$ of pores are micropores and $30 \%$ are macropores, and another quartzarenite with the same porosity but $30 \%$ are micropores and $70 \%$ are macropores. The first one is strongly more alterable than the second one. So the study of porosity is decisive in the field of building materials, first to predict its durability and then to assess the effectiveness of applied conservation products.

\section{Determination of pore system configuration}

\subsection{Previous techniques}

Many techniques have been used to estimate the pore space volume such as the pointcounting in thin section according to Gazzi-Dickinson's method (Ingersoll et al., 1984). The technique consists of saturating the pore space of the rock sample with colored resin in order to make it more visible and to facilitate the point-counting by the petrographic miroscope. 
Connected porosity can be also measured by introducing gas or liquid into the rock. Thanks to the volume of the introduced fluid, porosity can be calculated according standards such as UNE-EN 1936.

Mercury porosimetry is probably the most commonly indirect technique used to characterize the pore space allowing calculating the total connected porosity and its pore size distribution. But mercury porosimetry only measures pore access and real pore size was usually misestimated. This numerical model cannot describe faithfully the porous network configuration as the porous network is incorrectly simulated as a collection of cylindrical non-interconnected tubes that is very far from true pore shapes and network configuration. Therefore, the geometric complexity of pore space based on pore throats and pore bodies leads to ambiguities in the physical interpretation of mercury data and of other indirect methods. For example, as shown in Figure 1, although the average radius of both channels is similar, a fluid flow in channels B will show different properties from one moving through channel A. Hence, rocks having pores type A are more resistant to the freezing-thaw weathering than rock with a pore type B.

Images obtained by conventional techniques such as scanning electron microscopy are commonly used by several authors to characterize the pore network configuration but since SEM can only analyse the surface of simple (planar section or sample fragment), information about pore shape, pore throat and pores interconnection are not available.

Several attempt to obtain information about pore shape and pore interconnection have been processed (Krohn, 1988; Wong et al., 1989, Fredrich et al., 1993; Berryman and Blair, 1986; Thompson, 1991) allowing a tow-dementional (2D) representation which insufficient to describe a tree-dimentional (3D) objects such as the pore media.

Several researchers aware of this limitation developed innovative techniques to overcome this handicap (Pittman and Duschatko, 1970; Bourbie and Zinszner, 1985; Myer et al., 1992; Zinszner et al., 1997). Some techniques are effective like proposed by Lin et al. (1989) but are time consumer and tedious as critiqued by Fredrich (1999). X-ray computed tomography to generate 3D images has been used to image porosity distribution (Wellington and Vinegar, 1987), however, quantitative measurement are complicated (Brown et al., 1993; Fredrich et al 1994). More over a typical resolution is about $0.1-1 \mathrm{~mm}$ and is not sufficient to detail characterization of pores in the majority of rocks. Baldwin et al. (1996) and Doughty and Tomusta (1997) used the magnetic resonance imaging (MRI) for the same purpose, but

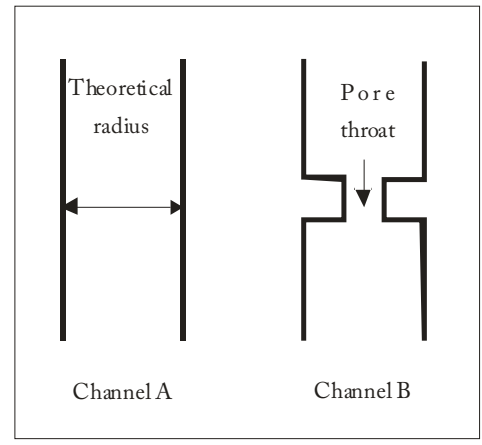

Fig. 1. Two channel geometries (A and B), with the same mean radius but with B containing a pore throat 
although the higher resolution than the X-ray CT $(25 \mu \mathrm{m})$ is not sufficient to characterize the pores rock media since the average pore radio of the majority of natural rock is about a few microns and can reach the nanometer.

\subsection{Contribution of LSCM}

LSCM can afford high-resolution optical images with depth selectivity. Thanks to its ability to acquire in-focus images from selected depths, images are acquired point-by-point and reconstructed with a computer, allowing three-dimensional reconstructions of pore network typology. Its high resolution allows also a better precision in 2D studies than with others conventional microscopy techniques. This high performance is needed in this kind of study to provide details and precision about connectivity, pore distribution and pore shape, critical parameters, to control fluid transfer and hence rock durablity. Several authors (Petford and Miller, 1990, 1993; Montoto et al., 1995; Pironon et al., 1998; Fredrich, 1999; Petford et al., 1999; Menéndez et al., 1999 and Zoghlami et al., 2004) obtained a very good results in improving the 3D porous network reconstruction leading to better understand mercury porosimetry data, usually misinterpreted due to a lack of the 3D pore network configuration.

The technique consists of saturating the pore space of the rock sample with a very low viscosity epoxy ( 60 cps) such as Epofix resin from Struers (Zoghlami and Gomez, 2004) doped with a fluorochrome such as araldite AY105 doped with Pylam Blue, with a butanone hardener (Petford et al., 1998). The wetting characteristics of the simple are generally improved if the sample is first flushed with a solvent such as acetone Fredrich (1999). Impregnation should be realized under vaccum to force the epoxy into the void space as deeper as possible.

Fredrich in 1999, decribed the methodology as following:

- $\quad$ Thorough mixing of the epoxy and the fluochrome added as a powder may take up to an hour, air is typically incorporated during the process

- The solution (fluochrome + epoxy) must be left a sufficient time under vacuum to allow a complete degassing before sample impregnation.

- Samples are impregnated under vacuum and left overnight to allow a complete penetration into the void space.

- $\quad$ Curing during $X$ time at $60^{\circ} \mathrm{C}$.

- Samples are slabbed and mounted on a glass slide.

- Finally, sample must be polished using standard abrasive polishing techniques, typically to a final finish with $0.05 \mu \mathrm{m}$ alumina.

Fredrich in 1999 has demonstrated by direct observation and measures that this procedure allows a successful epoxy penetration into craks about $200 \mathrm{~nm}$ of diameter. The choice of the fluorochrome is significant (Wilson, 1990). In fact, The absorption peak should be well matched to the wavelength as confocal system are communly equipped with either an argon ion laser with lines at $488 \mathrm{~nm}$ and 568, or a Krypton-argon mixed gas laser with lines at 488 $\mathrm{nm}, 568$ and $647 \mathrm{~nm}$. Fluorochromes must be resistant to photobleaching and must be excited effectively with one of the before cited wavelengths. Fluorochromes as Rodamine B used at a concentration of 1:200 dissolved well en epoxy and displayed a very good results. Epodye yellow dye from Struers used at a concentration of $5 \mathrm{gr} / \mathrm{L}$ displayed very good results (Zoghlami et al., 2004). Beside the influence of the used epoxy and fluorochrome on the images quality, there are many other facture that affect mainly gray level and the brightness of images. Among this factures, we can cite the opening of the confocal aperture, 
the laser intensity and the gain of the photomultiplier. The user must balance each of this simultaneously to arrive at an optimum result.

\section{Conservation product distribution}

In rock conservation field, some chemical products such as consolidants and waterrepellents are used as a protection and conservations means of deteriorated building rocks, especially in historical constructions and archeological objects.

The utility of a consolidant lies in re-establishing the cohesion of the particles in a deteriorated stone (Dukes, 1972; Torraca, 1975; Alessandrini et al., 1975). In addition, a good consolidant should meet performance requirements concerning durability, depth of penetration (Young et al., 1999), effect on stone porosity, effect on moisture transfer (Borselliet al., 1990; Dell'Agli et al., 2000) compatibility with stone, and effect on appearance (Biscontin et al., 1975). The porosity and pore size distribution of a stone may have a major effect on its durability. For example, the resistance of a given type of stone to frost and salt damage decreases as the proportion of fine pores increases (Hudec, 1978; Camaiti and Amoroso, 1997).

Water repellents are used to prevent or reduce water penetration into stonework, thus reducing its rate of decay. Parameters concerning treated rock durability, depth of water repellent penetration (Young et al., 1999), treated rock porosity, moisture transfer (Borselli et al., 1990; Dell'Agli et al., 2000) and rock appearance (Biscontin et al., 1975) are used to evaluate the quality of the water repellent. In turn, most of these characteristics mainly depend on the water repellent distribution in the pore network of the rock.

The application of consolidants and water repellents often causes changes in the pore-size distribution of the treated rocks (Esbert, 1993; Villegas et al., 1995; Alvarez De Buergo et al., 2004; Zoghlami and Gómez-Gras, 2004). A decrease or increase of micropores, are usually detected by mercury intrusion porosimetry, both effects are usually interpreted simplistically in the same way. When an increase in microporosity is detected, it is interpreted as a total sealing of the missing pores. When a decrease in microporosity occurs, it is interpreted as a partial sealing of originally larger pores (Esbert and Díaz-Pache, 1993). This general interpretation, applied to different kinds of rocks, is due to the lack of information about the real 3D configuration of the porous network in each type of rock. Some changes are accepted, while others are not. For exemple, a stone consolidant that reduces pore size without plugging may therefore be harmful in special conditions mainly if the weathering factor is freezing or salts. So, changes in treated rock must be controlled, mainly those affecting pore size distribution and pore network configuration as they govern the others properties. Moreover, without knowing the initial configuration of the porous network or the spacial distribution of the consolidant and the water-reppelent, it is very difficult to correctly interpret the effect of these products.

Mercury porosimetry was always used to characterise the porous network configuration of both untreated and treated rocks with conservation products (Sasse et al., 1993). But as shown previously, information provided by mercury porosimetry is insufficient to precisely understand the distribution of the conservation polymer within the rock's porous network and should be complemented with other techniques.

Scanning electron microscopy (SEM) has been the most commonly applied direct technique used in determining the distribution of conservation products in porous rocks (Esbert et al., 1990; Piacenti et al., 1993; Paterno and Charola, 2000; Alvarez De Buergo and Fort, 2001). Nevertheless, SEM allows analysis of sample surfaces only (rock fragments or thin sections). 
Hence, in these works, only 2D images of the surface of a treated sample were obtained, the effect of the consolidant and water-repellent in the porous network have to be deduced from mercury porosimetry data. In addition, the use of 2D images introduces further problems related to the interconnection of the porous network, as these often mask the true 3D topology (Petford et al., 1999).

In order to correctly interpret the effect of these products, it is essentially to know the initial configuration of the porous network and the spacial distribution of conservation products. SEM-EDX and X-ray micro-computed tomography, combined with specific 3D software, had been employed to determine the impregnation depth and distribution of consolidants and water repellents in several building materials (Ruiz de Argandoña et al., 2003; Mees et al., 2003; Cnudde et al., 2004; De Vetter et al., 2006; Rodríguez-Rey et al., 2006). Nevertheless, this arrangement of techniques is not easily available and is presently limited to detect pores larger than $10 \mu \mathrm{m}$. However, these techniques are not sufficient to characterize most of the natural rocks used as building materials if the average pore size of these materials can always reach the nanometer.

To improve the direct observations of conservation products distribution within the porous network of the building stone we proposed (Zoghlami and Gómez; 2004; Zoghlami et al., 2008) the LSCM as an innovative technique in the field of materials conservation. During the following case study, we will try to demonstrate how LSCM allows getting information, direct observation and measurement about porosity properties and conservation products distribution within the rock pore network.

\section{Case study}

\subsection{Used materials}

To realize the experiment we used sandstone widely used in the construction of the Tunisian monuments such as the aqueduct of Carthage and Uthina Romain site. It is a noncemented quartz-arenite, lithified by compaction and composed of quartz grains (69-84 \%), feldspars (mainly orthoclase; $0-1,1 \%)$, porosity (17-25\%) and clay minerals as matrix $(0-11 \%)$. Due to its homogenous mineralogical composition (Figure 2) and the simplicity of its pore network configuration formed by the void space let between the grains of quartz, constitute an ideal rock to show the contibution of LSCM in this field and how images obtained by LSCM can allow a better understood and evaluation of conservation product effectiveness.

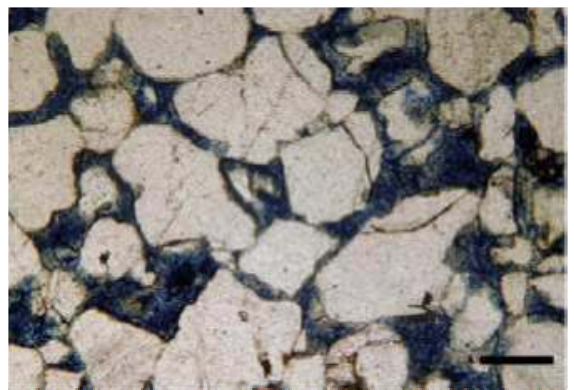

Fig. 2. Microphotograph in thin section showing, in blow porosity and in white grains of quartz. Scale $400 \mu \mathrm{m}$

To better understand the distribution of the consolidant, it is necessary to first to have an idea about the porous network configuration of the sandstone. 
Total porosity of the rock, determined by mercury intrusion porosimetry, showed high values (17-25\%). Macroporosity (pore diameter $>15 \mu \mathrm{m}$,) according to Goñi et al. (1968) and Bousquié (1980) represents a percentage of between 83.38 and $89.18 \%$, whereas microporosity ranges from between 8.65 and $14.78 \%$, indicative of the sandstone's macroporous character (Figure. 3). The mode of the pore-access size varied from between 20 and $30 \mu \mathrm{m}$, representing $60 \%$ to $80 \%$ of total porosity.

Mercury porosimety results show that most of the pores $(>80 \%)$ have a pore access diameter of between 20 and $40 \mu \mathrm{m}$, depending on the rock's grain size. The rest of the pores $(<20 \%)$ present a diameter pore access inferior to $15 \mu \mathrm{m}$ (micropores). However, this method only allows obtaining quantitative porosity data; it does not provide information on the arrangement of porosity, nor the way that pores are interconnected.

Fluorescence images of thin sections show that this sandstone has a very simple porous structure constituted by pore throats and pore bodies (Figure 4A). In general, pores displayed channel-like shapes with diameters smaller than $40 \mu \mathrm{m}$ (Figure 4B). Mega pores reaching up to $300 \mu \mathrm{m}$ in diameter were also observed. As the images of thin sections obtained by fluorescence microscopy were 2D, it was not possible to infer the degree of interconnection between both pore types; the real configuration of the porous network could not therefore be determined.

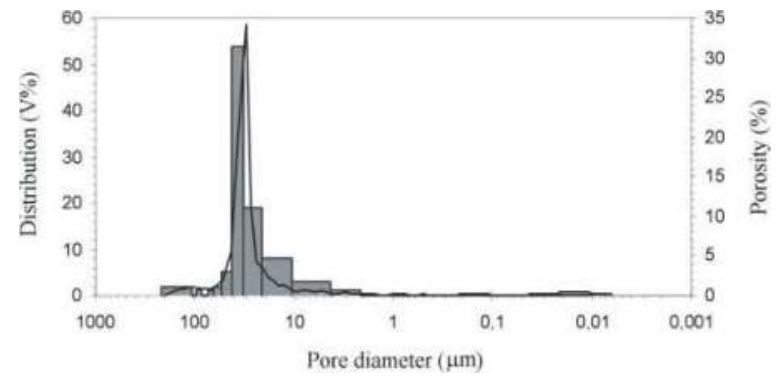

Fig. 3. Pore size distribution of the untreated sandstone simple

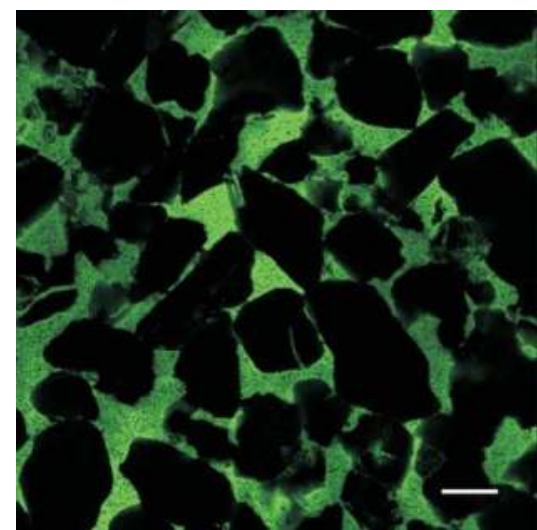

(A)

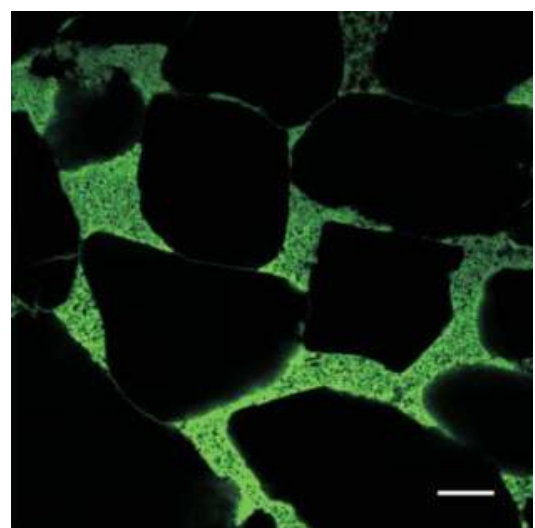

(B)

Fig. 4. LSCM images. (A) General aspect of the sandstone porosity. Bar length: $80 \mu \mathrm{m}$. (B) Detailed image of pores (communicated channels). Bar length: $40 \mu \mathrm{m}$. (C). 
As mercury porosimetry only measures pore access, real pore size was measured using LSCM. The obtained results showed that in fine-grained sandstones, pore sizes varied from between 50-60 $\mu \mathrm{m}$, and could reach up to $120 \mu \mathrm{m}$. In the medium-grained sandstones, the average main pore size was around $200 \mu \mathrm{m}$, reaching up to $600 \mu \mathrm{m}$, giving a macroporous character to the rock that allowed optimal interconnection between the pores that facilitated fluid circulation. The 3D reconstruction of the porous network (Figure 5) showed that it was constituted by a single pore system whose configuration only depends on grain arrangements and degree of compaction. The porous network was constituted by channels $(<40 \mu \mathrm{m}$ in diameter $)$ that may occasionally expand, giving rise to megapores of up to $300 \mu \mathrm{m}$ in diameter.

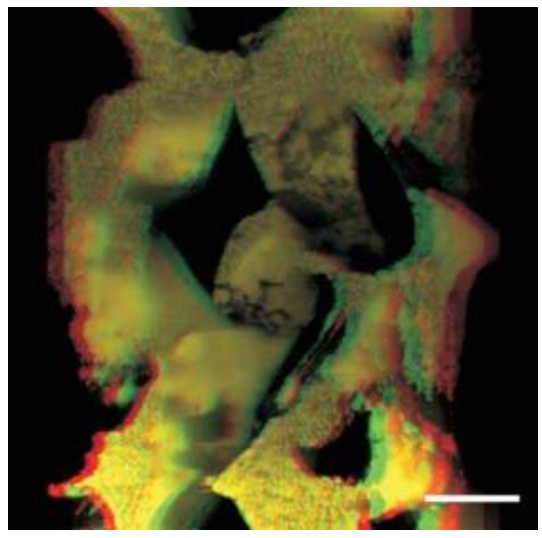

(A)

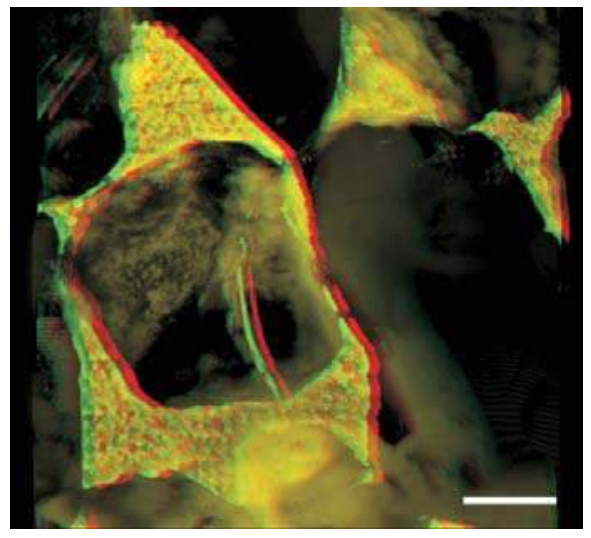

(B)

Fig. 5. (A) 3D reconstruction of the porous network. Bar length: $40 \mu \mathrm{m}$. (B) 3D pore detail. Bar length: $40 \mu \mathrm{m}$.

Combined LSCM and mercury intrusion porosimetry data allowed recognition of the fact that porosity was present as large pores, intercommunicated by channels that constitute pore accesses. Although of smaller size with respect to the main pores, these pore accesses were still large $(20-40 \mu \mathrm{m})$.

Hence, the 3-D reconstruction of the porous network in the sandstone facilitated not only an understanding of the effect of consolidants on pore-size distribution and on the network configuration of the rock, but also allowed correct interpretation of the porosimetry data.

\subsection{Preparing samples}

In order to determine the distribution of the consolidant within the porous network using LSCM (Zoghlami and Gómez, 2004), sample were prepared in accordance with the following procedure:

- $\quad$ Addition of powdered fluorochrome to the consolidant solution (5gr/11 of consolidant).

- The obtained solution was left for one hour to allow total dissolution of the Fluorochrome in the consolidant solution.

- Brush application of the doped consolidant and watter repellent solution to the sandstone samples $(5 \times 5 \times 5 \mathrm{~cm})$.

- Curing treated samples for one month with doped consolidant to permit complete polymerisation of the conservation products. 
- Preparation and mounting of polished planar sections (thickness $>100 \mu \mathrm{m}$ ) on a glass slide.

\subsection{Consolidant distribution into the pore network of the sandstone and LSCM contribution}

In order to determine the percentage of porosity and its pore size distribution, IMP was used to detetect changes between untreated and treated sandstone simples with the consolidant.

Compared to untreated samples, samples treated with consolidants show a moderate decrease in total porosity. Consolidants affected pore-size distribution by producing a decrease in macroporosity and an increase in microporosity, especially for pores of less than $10 \mu \mathrm{m}$ in diameter. Figure 6 shows that a decrease occurred in the amount of pores having sizes of between 20 and $40 \mu \mathrm{m}$, the most abundant range in this rock. Additionally, there was the appearance of pores having a smaller diameter $(<10 \mu \mathrm{m})$. The presence of this new pore population might be explained by a partial sealing of pores of between 20 and $40 \mu \mathrm{m}$ in diameter. The effect of partial sealing in different treated rocks has already been discussed by Esbert and Díaz-Pache (1993).

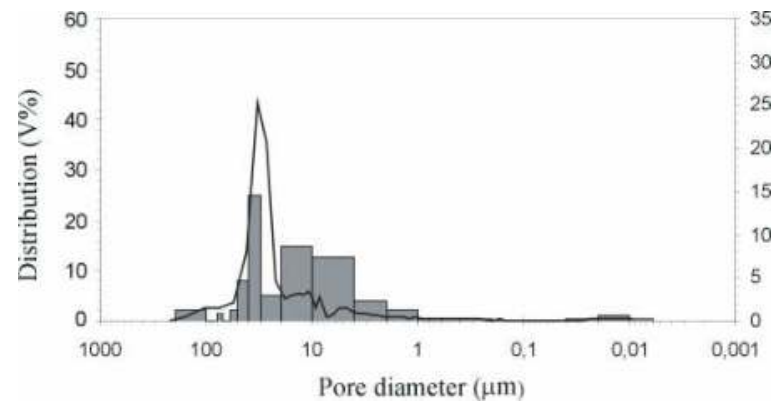

Fig. 6. Pore size distribution of the treated sandstone simple with consolidant (2)

In thin sections, LSCM observations showed that grain surfaces were covered by a discontinuous coating film. When grains were very close, consolidants usually formed meniscus plugging only in the small throats (diameter $<40 \mu \mathrm{m}$ ) (Figures 7 ).

$3 \mathrm{D}$ reconstruction (Figure 8A) showed that consolidants filled the pore-network throats (pore diameter of less than $40 \mu \mathrm{m})$, whereas megapores were covered by a very thin (1-2 $\mu \mathrm{m})$ coating film of consolidant (Figure $7 \mathrm{~B}$ ). It is worth observing that the consolidant used in our experiment developed cracks reaching up to $10 \mu \mathrm{m}$ in diameter. These cracks developed a network of small channels interconnected between both themselves and the megapores (Figure 8B).

As shown previously, mercury porosimetry data from samples treated with consolidants showed a microporosity increase with respect to untreated samples, a decrease in pores with diameters of between 20 and $40 \mu \mathrm{m}$ and the development of new pores with diameters

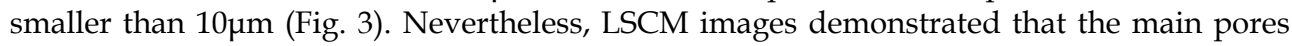
sizes (mega pores) were not affected by the application of consolidants, due to the development of a very thin coating film around the grains. 3D reconstruction showed that consolidant is concentrated within throats having a pore diameter smaller than $40 \mu \mathrm{m}$ and that cracks developed in the polymer could reach up to $10 \mu \mathrm{m}$ in size. Therefore, the increase in microporosity can be attributed to the formation of microfissures probably due to the 
type of catalyst used; this probably destabilizes the polymer used as consolidant, as reported by Brus and Kotlik (1996). These results also showed that a correct interpretation of the mercury porosimetry data needs to consider the formation of micro-cracks during the application of a consolidant.

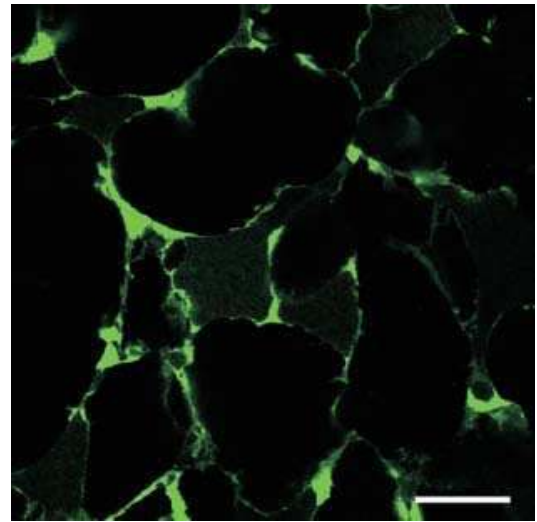

(A)

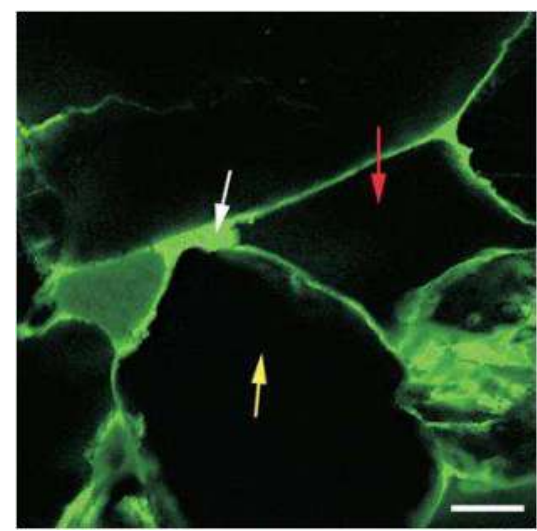

(B)

Fig. 7. Fluorescence microscope images. Distribution of consolidant (A) and (B). Red arrow: porosity; yellow arrow: grain; white arrow: consolidant. Bar length: $80 \mu \mathrm{m}$.

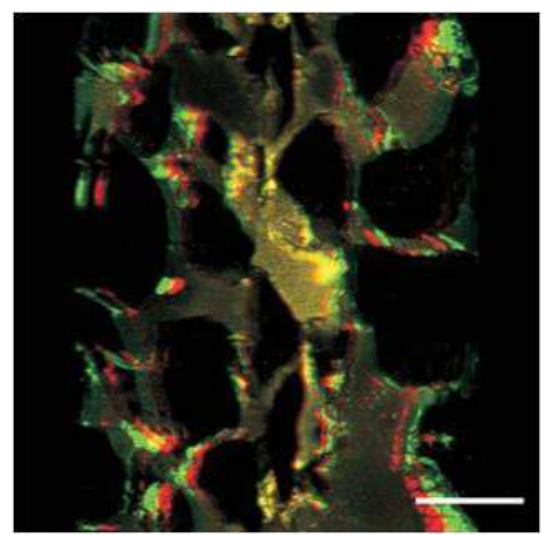

(A)

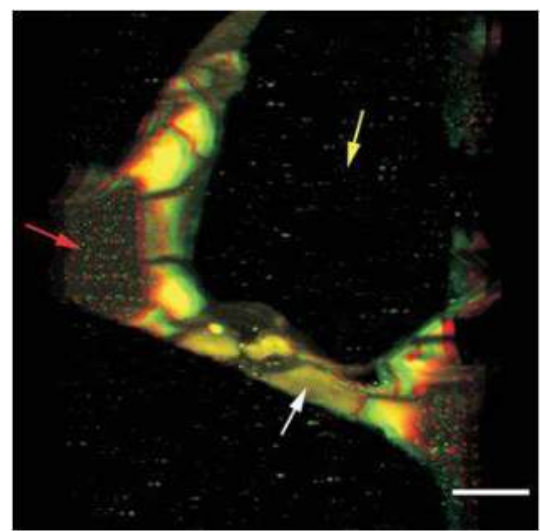

(B)

Fig. 8. 3D reconstruction. (A) Image shows that consolidant is concentrated in throats. Bar length: $80 \mu \mathrm{m}$. (B) Image shows microfissures in consolidant. Bar length: $40 \mu \mathrm{m}$.

\subsection{Watter repellent distribution into pore network of the sandstone and LSCM contribution}

The studied treated and untreated samples used for this experiment were obtained from the same stone prism $(10 \times 5 \times 5 \mathrm{~cm})$ that was divided into 2 cubes $(5 \times 5 \times 5 \mathrm{~cm})$. One of them was treated with a doped water repellent solution, as explained below, and used for the LSCM 
imaging and mercury intrusion porosimetry (Figure 9). The other one was treated with plain water repellent and employed in SEM observations, taking into account that the penetration depth of the water repellent applied on the stone cube was $1.5 \mathrm{~cm}$, which was determined by microdrops, wetting and salt crystallisation tests (Zoghlami, 2003). The used water repellent is a Polymethyl-siloxan commercialized in water emulsion by several companies. In order to distinguish the water repellent and determine its distribution within the pore network using LSCM, the conservation product had to be doped, so that part of the sandstone samples were prepared following the methodology previously described.

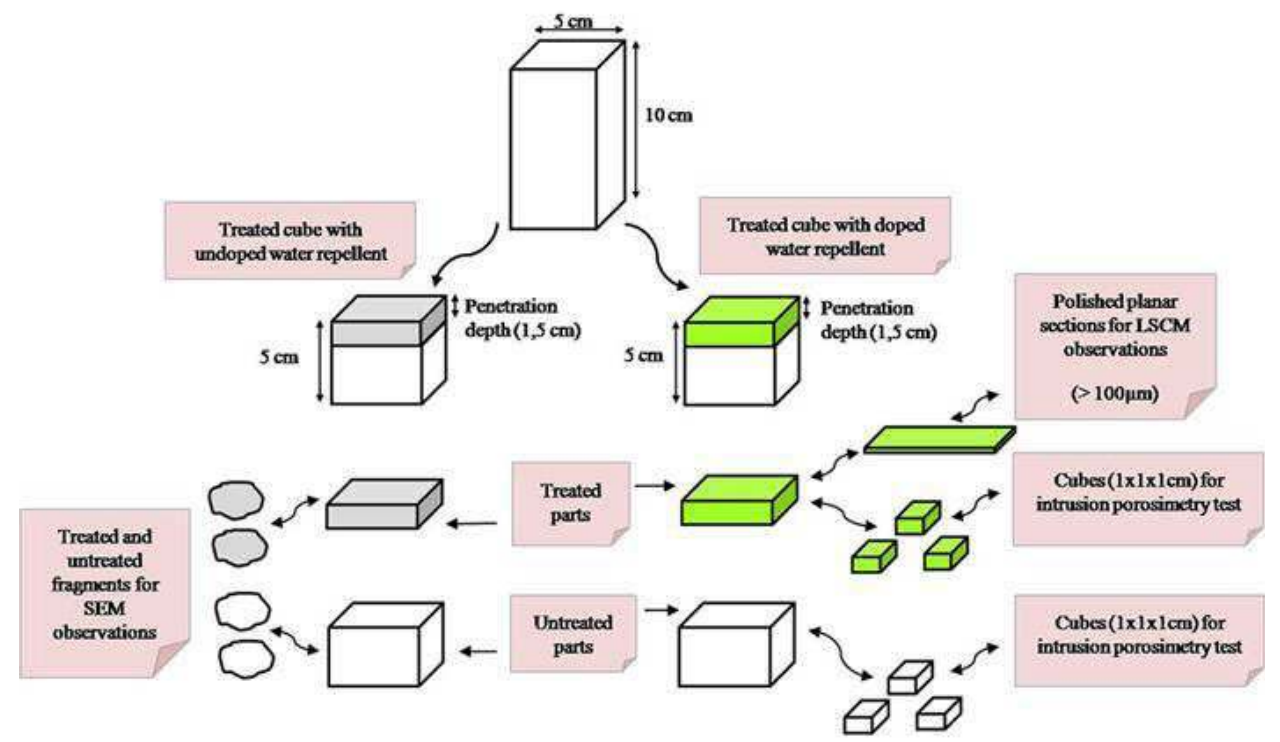

Fig. 9. Chart of sample distribution for the experimental procedures $60 \times 35 \mathrm{~mm}(300 \times 300 \mathrm{DPI})$

The porosity of the samples treated with water repellent was measured by mercury intrusion porosimetry. The data obtained did not change much the pore size distribution with respect to the untreated samples (Figure $10 \mathrm{~A}$ and B). However, a small reduction of total porosity occurred $(2.29 \%)$ which affected both macro and microporosity percentages. The porosity reduction was more pronounced in macroporosity $(1.66 \%)$ than in microporosity $(0.63 \%)$. Nevertheless, this affected the porosity distribution, as the microporosity distribution value decreased, from 10.01 to $8.01 \%$, and therefore the macroporosity distribution value increased from 89.99 to $91.99 \%$. All pore sizes decreased in diameter as was observed in the shift towards the right hand-side of the pore size intervals in the porosity distribution histograms. Similarly, the average pore diameter decreased from 33.40 to $32.21 \mu \mathrm{m}$ and the pore diameter mode adjusted varying from the $30-40 \mu \mathrm{m}$ to the $20-30 \mu \mathrm{m}$ intervals.

SEM observations of treated rock samples showed that the water repellent formed a continuous film that completely covered the sandstone grains (Figure 11) but did not occlude the macroporosity. The optical similitude under SEM between the conservation polymer, which formed a silica gel, and the quartz and feldspar grains of this sandstone disallowed the accurate thickness measurement of this film. 

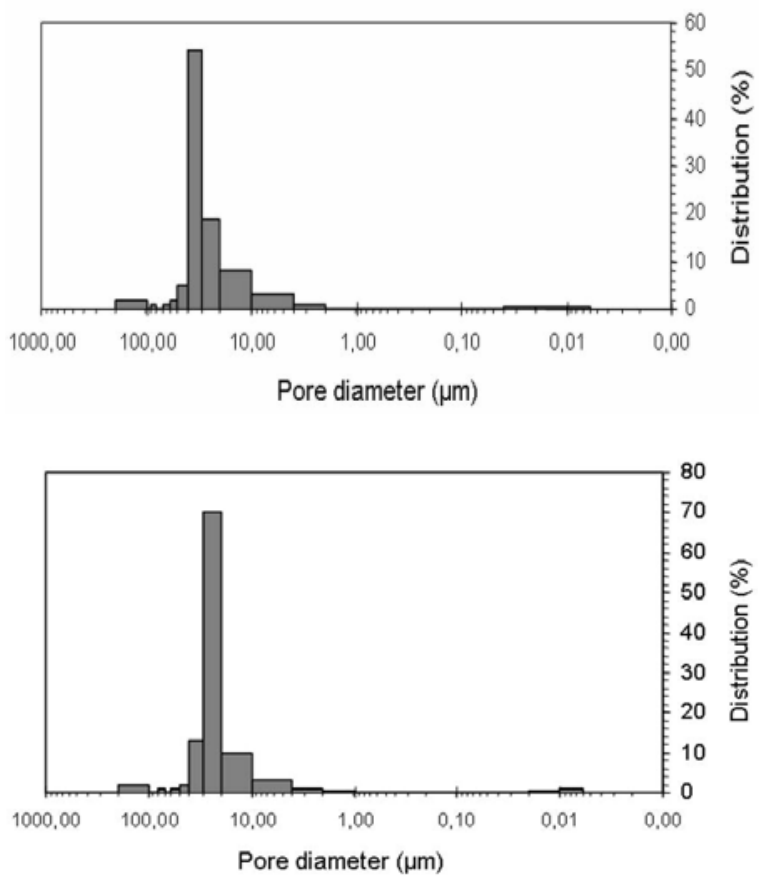

Fig. 10. Pore-size distribution diagrams obtained by mercury porosimetry test.

(A) Untreated sandstone (B) Treated sandstone with THE328 water repellent.

LSCM observations of water repellent in thin sections allowed the easy measurement of the coating film: it varied between 1.5 and $2 \mu \mathrm{m}$ (Figure 12). Moreover, the water repellent polymer formed meniscuses where the sandstone grains were very close and plugged the throats whose diameters were less than 3-4 $\mu \mathrm{m}$. The visualization and differentiation of the water repellent distribution through the pore network over a section $100 \mu \mathrm{m}$ thick (Figure 12), which is possible using specific software, corroborated that the coating film had a homogeneous and continuous volumetric distribution in the three spatial directions.

The mercury intrusion porosimetry data reported, as expected, a small decrease $(2.29 \%)$ in the total porosity of the treated samples. Although both macro and microporosity absolute values were reduced, the macroporosity distribution value increased by $2 \%$. SEM imaging of the siliceous sample treated with THE 328 allowed the visualization of the water repellent polymer coating the grains and even the closure of some pores, but it was too difficult to measure the thickness of the water repellent film through the pore network over the penetration depth profile. It is therefore complicated to qualitatively explain, in this case, the porosity change in the treated samples with the SEM observations.

Alternatively, water repellent stained with fluorochrome was effortlessly observed under LSCM as green marks (Figure 12 and 13), thus achieving a successful differentiation from the siliceous components of the rock and its porosity. It was therefore simple to determine, with LSCM, the effective penetration depth of the product and to measure the thickness of the protective film formed over the grains as well as the plugged pore diameters. Fluorescence and 3D imaging of water repellent distribution and porosity by LSCM helps 


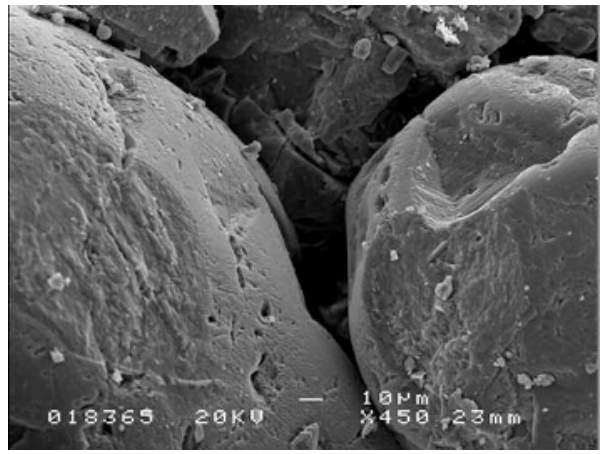

(A)

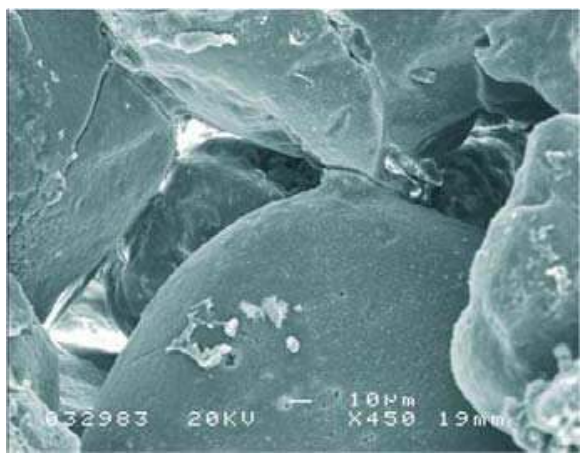

(B)

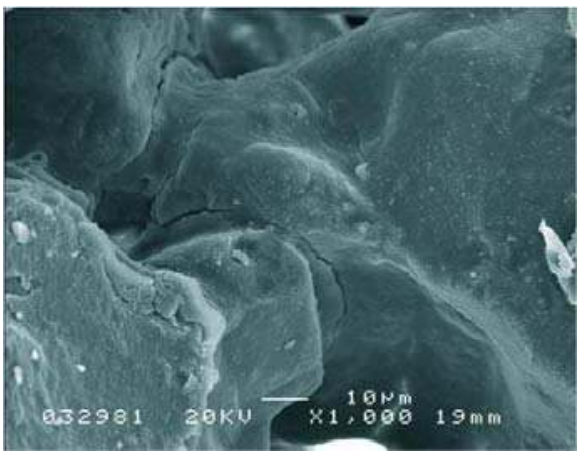

(C)

Fig. 11. SEM images of the sandstone. (A) Untreated sample. (B) Large view of the sample treated with THE328 water repellent. (C) Detailed photograph of the water repellent film between grains.

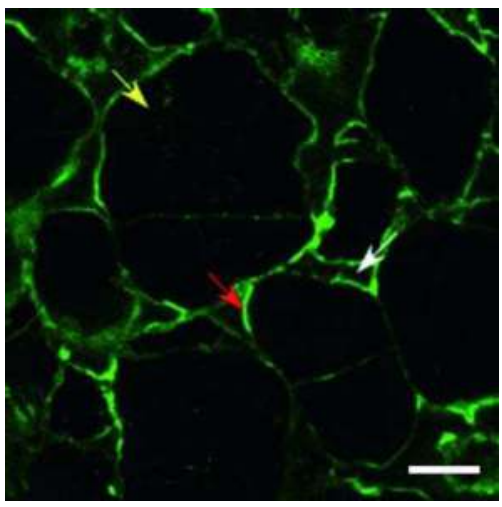

Fig. 12. Thin sections of a sample treated with THE328 water repellent observed with LSCM under fluorescence light. (A) Regular view where the red arrow points to the coating film (green), the yellow arrow a quartz grain, and the white arrow the porosity. Bar length: $40 \mu \mathrm{m}$. 
with the interpretation of even the minor changes in porosity. This case study shows that the decrease of 3-4 $\mu \mathrm{m}$ in the diameter of all pores is the root of the shift towards the right hand side of the pore size intervals in the distribution histogram. As the displacement also affected the mode interval or average pore diameter, this shift had an impact in the new distribution between macro and microporosity in the samples after treatment because the modal pore size was close to the $15 \mu \mathrm{m}$ value (the limit between macro and microporosity fields).

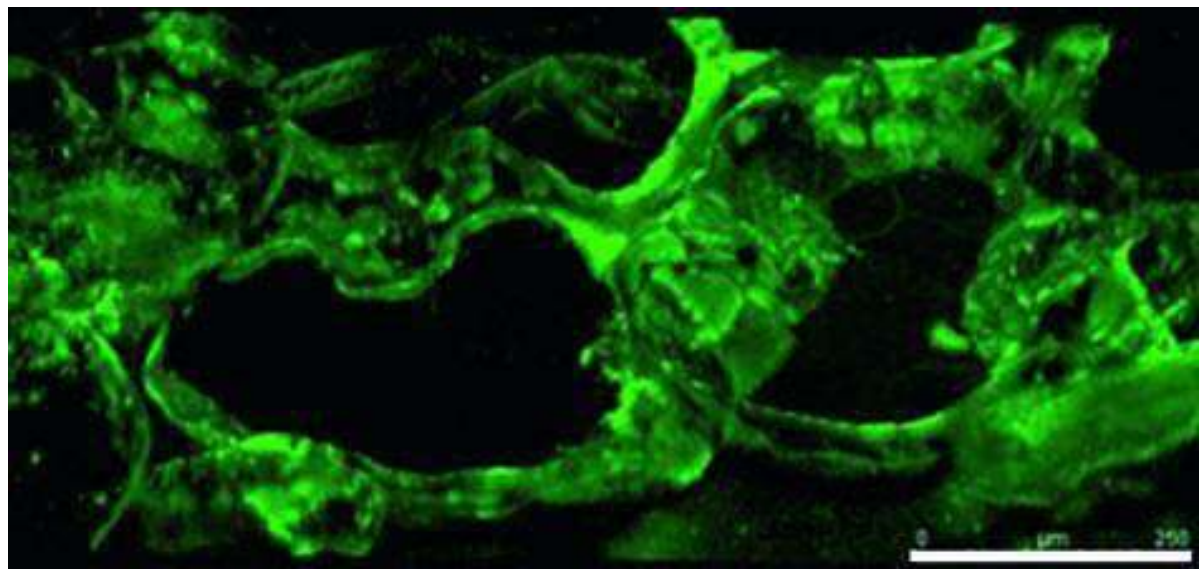

Fig. 13. 3D reconstruction obtained by LSCM of a section $1005 \mathrm{~m}$ thick of the water repellent distribution within the sandstone porous network. Bar length: $2505 \mathrm{~m}$.

\section{Conclusion}

As demonstrated by the case study below, LSCM has proved to be a useful technique in achieving a tridimentional reconstruction of a rock's porous network, and in understanding quantitative porosity data obtained by mercury porosimetry. In this study, LSCM has been used for the first time to determine the 3D distribution of conservation products within the pore network of the sandstone. Thorough observations of consolidant and a watter repellent distribution within the rock's pores has obtained enabling an inderstanding of the consolidant's and water reppelent effect on the pore-network configuration and interconnection, both of these being important properties affecting rock durability, since they control fluids flow. So a correct assessment of the effectiveness of these products has been allowed and the usefulness of LSCM in building-stone preservation studies has therefore been demonstrated.

Data obtained confirms that LSCM is a very useful technique that complements and helps to integrate the quantitative porosity data as well as SEM observations.

The principal limitation of this technique is the reduced penetration depth. Until now, penetration depth about $250 \mu \mathrm{m}$ can be achieved before significant image degradation is apparent. But this is insufficient especially in rock materials to describe faithfully the pore media. In reality, deeper penetration can be obtained by greater laser intensity. Nevertheless, a high laser intensity increases the risk of photobleaching. 


\section{References}

Adler, P.M. 1992. Porous media: Geometry and transport, 544 pp., Butterworth-Heinemann Series in chemical Enginneering, Stoneham, Mass.

Alessandrini G.; Del Fa, C.M.; Rossi-Doria, P.; Tabasso, M. \& Vannucci, S. (1975). Treatment of Stone in Monuments. A Review of Principles and Processes. Proceeding of the International Symposium of the Conservation of Stone I, pp. 635-650, Bologna. Italy.

Alvarez De Buergo, M.; Fort, R. \& Gómez-Heras, M. (2004). Contributions of Scanning Electron Microscopy to the assessment of the effectiveness of stone conservation treatments. Scanning, Vol. 26, 41-47.

Alvarez De Buergo, M. \& Fort ,R. (2001). Basic methodology for the assessment and selection of water-repellent treatments applied on carbonatic materials. Progress in Organic Coatings, Vol.43, 258-266.

Álvarez De Buergo, M.; García Calleja, M.A.; Gónzalez Limon, T. \& Soriano Carillo, J. (1994). Estudio de la eficacia y durabilidad de los tratamientos de conservación aplicados a los materiales pétreos del Claustro de San Juan de Duero en Soria. Ingeniería Civil, Vol. 9, 89-97.

Baldwin, C.A.; Sederman, A.J.; Matntelle, M.D.; Alexander, P. \& Gladden, L.F. (1996). Determination and characterization of the structure of a pore space from 3D volume images. J. Colloid Interface Sci., Vol. 181, 79-92.

Berryman, J.K. \& Blair, S.C. 1986. Use of digital image analysis to estimate fluid permeability of porous materials: Application of tow-point correlation functions. J. Appl. Phys., Vol.60, 1930-1938.

Biscontin, G.; Frascati, S. \& Marchesini, L. (1975). Colour Variations in Old Bricks and Stones as a Result of Consolidation with Resin. Proceeding of the International Symposium of the Conservation of Stone I., pp 741-747, Bologna. Italy.

Borselli, G. ; Camaiti, M. ; Pasetti, A., Maravelaky, P. \& Matteoli, U. (1990). Protettivi impiegati nella conservazione dei materiali lapidei: storia, impieghi, sviluppi. L'Édilizia. 1/2: 67-78.

Bourbie, T. \& Zinszner, B. (1985). Hydrolic and acoustic properties as a function of porosity in Fontainebleau sandstone. J. Geophys. Res., Vol. 90, 11524-11532.

Brown, G.O.; Stone, M.L., \& Gazin, J.E. (1993). Accuracy of gamma ray computerized topography in porous media. Water Res., 29: 479-486.

Bousquié, P. ; Pellerin, F.M.; Struillou, R. \& Arnould, M. (1980). Contribution de la porosimetrie au mercure a l'étude de quelques propriétés de roches carbonatées. In: Wolters R, editor.Materials and engineering geology. Bull Int Assoc Eng Geol., Vol. 22, 225-232.

Brus, J. \& Kotlík, P. (1996). Consolidación de la piedra con mezclas de Alcoxisilanos y polímeros acrílicos. Cuadernos sobre conservación, Vol. 41, N².

Camaiti, M., \& Amoroso, G.G. (1997). Scienza dei materiali e restauro. La pietra: dalli mani degli artisti e delli scalpellini a quelle dei chimici macromolicolari , 320 pp, Alinea ediytice srl- Firenze.

Cnudde, V.; Cnudde, J.P., Dupuis, C. \& Jacobs, P.J.S. (2004). X-ray micro-CT used for the localization of water repellents and consolidants inside natural building stones. Mater Charact, Vol. 53, 259-271. 
Dell' Agli, G.; Ferone, C., Mascolo, G.; Marino, O. \& Vitale, A. (2000). Durability of tufaceous stones treated with protection and consolidation products. 9th international congress on deterioration and conservation of stone. Venice, Italy. pp 379-386.

Doughty, D.A. \& Tomutsa, L. (1997). Imaging pore structure and connectivity in high resolution NMR microscopy. Int. J. Rock Mech. Min. Sci. 30: 691-697.

Dullien, F.A.L.( 1992). Porous media: Fluid transport and pore structure, $2^{\text {nd }}$ ed., Academic Press, New York.

Esbert, R.M. \& Díaz-Pache, F. (1993). Influence of petrographical characteristics in the penetration of consolidants in porous building stones. Mater construcc. Vol. 43, No230. 25-36.

Esbert, R.M.; Grossi, C.M.; Valdeon, J.; Ordaz, F.J.; Alonso, F.J. \& Marcos, R.M. (1990). Laboratry study for stone conservation at the Cathedral of Murcia. Mater construcc. Vol. 40, 217. 5-15.

Esbert, R.M. (1993). The use of surface protectants: the current situation in Spain. Mater Construcc. Vol. 43, No 229. 5-16.

Fredrich, J.T.; Greaves, K.H. \& Martin, J.W. (1993). Pore geometry and transport properties of Fantainebleau sandstone, Int. J. Rock Mech. Min. Sci., Vol. 30, 691-697.

Fredrich, J.T., Martin, J.W. and Owen, L.B., 1994. Application of X-ray computerized tomography for non-destructive mesurment of physical properties of NTS tuff, Deffens Nuclear Agency, DNA-TR-93-189, 121 pp., Alexandria, Virginia.

Fredrich, J.T. (1999). 3D Imaging of porous Media using Laser Scanning Confocal Microscopy with Application to Microscale Transport Process. Phys. Chem. Earth, Vol. 24, 551-561.

Gómez-Gras, D., \& Zoghlami, K. (2003). Procedencia de las areniscas de la unidad superior de la Fm. Fortuna en el NE de Túnez. Geotemas, Vol. 5, 109-111.

Goñi, J. ; Ragot, J.P. \& Sima, A. (1968). Méthode d'etude du champ microfissural des mineraux et des roches et possibilités d'application en géologie. Bull. Bur. Rech. Geol. Min. Section 2: Geologie des Gites Mineraux, Vol. 4, 51-86.

Hudec, P.P. (1978). Rock Weathering on the Molecular Level, In: Decay and Preservation of Stone, Engineering Geology Case Histories. The Geological Society of America. Boulder, Vol. 11, 47-51.

Ingersoll, R.V.; Bullard, T.F; Grimm, J.P.; Pickle, J.D. \& Sores, S.W. (1984): The effect of grain size on deterial modes: a test of Gazzi-Dickinson point-counting model. Jour. Sediment. Petrol., Vol. 54, 103-116.

Krohn, C.E. (1988). Sandstone fractal and Euclidean pore volume distribution. J. geophys. Res. Vol. 93, 3286-3296.

Menéndez, B.; David, C. \& Darot M. (1999). A study of the Crack Network in Thermally and Mechanically Cracked Granite Samples using Confocal Scanning Laser Microscopy. Phys. Chem. Earth, Vol. 24, 627-632.

Montoto, M.; Martinez-Nistal, A.; Rodriguez-Rey, A.; Fernandez-Merato, N. \& Soriano P. (1995). Microfractography of grantic rocks Ander confocal scanning laser microscopy. J. microscopy, Vol. 177, 138-149.

Myer, L.R.; Kemeny, J.M.; Zheng, Z.; Suarez, R.; Ewy, R.T. \& Cook, N.G.W. (1992). Extensile cracking in porous rock under differential compressive stress, In: Micromechanical Modelling of Quasi-Brittle Materials Behavior, V.C.Li (ed), Appl. Mech.Rev., Vol. 45, 263-280. 
Paterno, M.C. \& Charola, A.E. (2000). Preliminary studies for the consolidation of Guadalupe tuff from the Philippines. 9th international congress on deterioration and conservation of stone. Venice, Italy. pp 155-163.

Petford, N., Davidson, G., \& Miller, J.A. (1999). Pore structure determination using Confocal Scanning Laser Microscopy. Phys. Chem. Earth., Vol. 24, 563-567.

Petford, N.; Miller, J.A. (1990). SLM confocal microscopy: an improved way of viewing fission tracks. J. Geol. Soc. London, Vol. 147, 217-218.

Petford, N. \& Miller, J.A. (1993). The study of fission tracks and other crystalline defects using CSLM. J. Microscopy, Vol. 170, 201-212.

Piacenti, F., Camaiti, M., Mangalli del Fà C. \& Scala, A. (1993). Fluorinated Aggregating materials for stone. Conserv Stone and other Mater, pp 740-747.

Pironon, J.; Canals, M., Dubessy, J., Walgenwitz, F. \& Laplace-Builhe, C. (1998). Volumetric reconstruction of individual oil inclusions by CSLM. Eur. J. Mineral ,10: 1143-1150.

Pittman, E.D. \& Duschatko, R.W. (1970). Use of pore casts and scanning electron microscopy to study pore geometry. J.Sed. Petr., Vol. 40,1153-1157.

Rodríguez-Rey, A.; Ruiz de Argandoña, V.G; Calleja L, Suárez del Rio, L.M., Celorio, C. (2006). Consolidants Influence on the Sandstones Capillarity. X-ray Study. Advances in X-ray Tomography for Geomaterials. ISTE, Ltd., UK, pp. 381-387.

Ruiz de Argandoña, V.G.; Rodríguez-Rey, A., Celorio , C., Calleja, L. \& Suárez del Río, L.M. (2003). Characterization by X-ray computed tomography of water absorption in a limestone used as building stone in the Oviedo Catedral (Spain), Mees F, Swennen R, Van Geet $M$ and and Jacobs P. (eds): Applications of X-ray Computed Tomography in the Geosciences. Geological Society, London, Special Publications, Vol. $215,127-134$.

Sahimi, M. (1995). Flow and transport in porous media and fractured rock, 482 pp.,VCH, Weinhein, FRG.

Sasse, H.R.; Honsinger, D., Schwamborn, B. (1993). "PINS" - New technology in porous stone conservation. Conservation of stone and other materials. 705-715.

Thompson, A. H. (1991). Fractals in rock physics. Ann. Rev. Earth Planet. Sci. Vol. 19, 237262.

Torraca, G. (1975). Treatment of Stone in Monuments. A Review of Principles and Processes Proceeding of the International Symposium of the Conservation of Stone, pp. 297- 315. Bologna, Italy.

Wellington, S.L. \& Vinegar, J.J. (1987). X-ray computed tomography. J. Pet. Tech. Vol. 39, 885-898.

Villegas, R., Martín, L., Vale J.F. \& Bello, M.A. (1995). Characterization and conservation of the stone used in the cathedral of Granada, Spain. Mater Construcc., Vol. 45, 240. 1735.

Villegas, R. \& Vale Parapar, J.F. (1993). Evaluación de tratamientos de hidrofugación aplicados a piedras de catedrales andaluzas. III.- Ensayo de alteración acelerada en atmósfera contaminada. Mater construcc. Vol. 43, ํ232, 25-38.

Wheeler, G. (1992). Comparative strengthening of several consolidants on Wallace sandstone and India limestone. Proceedings of the 7th International Congress on Deterioration of Stone. pp 1033-1042. Lisbon, Portugal. 
Wilson, T. (1990). The role of the pinhole in confocal imaging systems. In handbook of biological Confocal microscopy, Pawley, J.B. (ed.), 113-126, Plenum Press, New York, NY.

Wong, T.F., Fredrich, J.T., and Gwanmesia, G.D., 1989. Crack aperture statistic and pore space fracture geometry of Westerly granite and Rutland quartzite: implication for an elasticcontact model of rock compressibility. J. Geophys. Res., Vol. 94, N¹0, 26710, 278.

Young, M.E; Murray, M., Cordiner, P. (1999). Stone consolidants and chemical treatments in Scotland. Report to historic Scotland. 298 p.

Zinszner, B., Johnson, P.A., Rasolofosaon, P. N.J. (1997). Influence of change in physical state on elastic nonlinear response in rock: Significance of effective pressure and water saturation. J. Geophys. Res. Vol. 102, 8105-8180.

Zoghlami, K; Gómez-Gras D, Álvarez, A. \& De Luxán, M.P. (2004). Intrinsic factors that condition the physical behaviour and the durability of the Miocene sandstones used in the construction of the Roman aqueduct of Zaghouan-Carthage. Mater Construcc.Vol. 54, N²76. 29-41.

Zoghlami, K., Gómez-Gras, D., Álvarez, A. \& De Luxán MP. (2005). Evaluation of consolidating and water repellent treatments applied to the miocene sandstone used in Tunisian Heritage Monuments. Mater Construcc. Vol. 55, №. 277, 25-39.

Zoghlami, K., Gómez-Gras, D. (2004). Determination of the distribution of consolidants and Interpretation of Mercury Porosimetry Data in a Sandstone Pore network Using LSCM. Microsc Res Tech. Vol. 65, 270-275. 




\author{
Laser Scanning, Theory and Applications \\ Edited by Prof. Chau-Chang Wang
}

ISBN 978-953-307-205-0

Hard cover, 566 pages

Publisher InTech

Published online 26, April, 2011

Published in print edition April, 2011

Ever since the invention of laser by Schawlow and Townes in 1958, various innovative ideas of laser-based applications emerge very year. At the same time, scientists and engineers keep on improving laser's power density, size, and cost which patch up the gap between theories and implementations. More importantly, our everyday life is changed and influenced by lasers even though we may not be fully aware of its existence. For example, it is there in cross-continent phone calls, price tag scanning in supermarkets, pointers in the classrooms, printers in the offices, accurate metal cutting in machine shops, etc. In this volume, we focus the recent developments related to laser scanning, a very powerful technique used in features detection and measurement. We invited researchers who do fundamental works in laser scanning theories or apply the principles of laser scanning to tackle problems encountered in medicine, geodesic survey, biology and archaeology. Twenty-eight chapters contributed by authors around the world to constitute this comprehensive book.

\title{
How to reference
}

In order to correctly reference this scholarly work, feel free to copy and paste the following:

Zoghlami, K. and Gomez Gras, D. (2011). Laser Scanning Confocal Microscopy Characterization of Conservation Products Distribution in Building Stone Porous Network, Laser Scanning, Theory and Applications, Prof. Chau-Chang Wang (Ed.), ISBN: 978-953-307-205-0, InTech, Available from: http://www.intechopen.com/books/laser-scanning-theory-and-applications/laser-scanning-confocalmicroscopy-characterization-of-conservation-products-distribution-in-buildin

\section{INTECH}

open science | open minds

\section{InTech Europe}

University Campus STeP Ri

Slavka Krautzeka 83/A

51000 Rijeka, Croatia

Phone: +385 (51) 770447

Fax: +385 (51) 686166

www.intechopen.com

\section{InTech China}

Unit 405, Office Block, Hotel Equatorial Shanghai

No.65, Yan An Road (West), Shanghai, 200040, China 中国上海市延安西路65号上海国际贵都大饭店办公楼 405 单元

Phone: $+86-21-62489820$

Fax: +86-21-62489821 
(C) 2011 The Author(s). Licensee IntechOpen. This chapter is distributed under the terms of the Creative Commons Attribution-NonCommercialShareAlike-3.0 License, which permits use, distribution and reproduction for non-commercial purposes, provided the original is properly cited and derivative works building on this content are distributed under the same license. 